\title{
DIAGNOSING GRANULOMATOUS DISEASE DURING APPENDECTOMY
}

\author{
Atilla Senayli ${ }^{1}$ \\ ${ }^{1}$ Yozgat Bozok University
}

September 29, 2021

\begin{abstract}
Difficulties during surgery are uncommon situations in appendectomy. For granulomatous appendicitis, literature is insufficient about surgical findings. The procedure of a 17-year-old male patient was a struggle due to adhesions. I thought a surgeon could expect granulomatous diseases by evaluating the macroscopic appearance of the appendix during surgical procedure.
\end{abstract}

\section{Hosted file}

Diagnosing Granulomatous Disease During Appendectomy.doc available at https://authorea.com/ users/438535/articles/539726-diagnosing-granulomatous-disease-during-appendectomy 